\title{
Jejunal perforations in a peritoneal dialysis patient with peritonitis: A case report
}

\author{
Periton diyalizi yapan peritonitli hastada jejunal perforasyonlar: vaka sunumu \\ Havva Cilan*, Murat Hayri Sipahioğlu**, Nilüfer Oğuzhan ${ }^{* * *}$, Öztürk Ateş**, İsmail Koçyiğit ${ }^{* *}$, \\ Bülent Tokgöz ${ }^{* *}$, Oktay Oymak ${ }^{* *}$, Cengiz Utaş** \\ *Mardin Devlet Hastanesi, Mardin \\ ${ }^{* * E}$ rciyes Üniversitesi, Tıp Fakültesi, Iç Hastalıkları AD, Nefroloji BD, Kayseri \\ ${ }^{* * * K a y s e r i ~ D e v l e t ~ H a s t a n e s i, ~ K a y s e r i ~}$
}

\begin{abstract}
A 73-year-old man maintained on continuous ambulatory peritoneal dialysis for 3 years, presented to our hospital with chief complaints of abdominal pain, fever and a cloudy dialysate. He was treated empirically with intraperitoneal cefazolin and amikacin for suspected PD-related peritonitis. On the third day, he developed jejunal perforations. A laparotomy was performed, revealing perforations of the jejenum. The perforations were sutured primarily. After the surgery, there was anastomotic leakage from the primary suture region. He died from sepsis-associated cardiovascular collapse.
\end{abstract}

Pam Med J 2014;7(1):67-69

Key words: jejunal perforation, peritoneal dialysis, peritonitis.

\section{Özet}

3 yıldır periton diyalizi yapmakta olan 73 yaşındaki erkek hasta hastanemize karın ağrısı, ateş ve bulanık diyalizat nedeniyle başvurdu. Hastaya periton diyalizi ilişkili peritonit şüphesi ile intraperitoneal sefazol ve amikasin tedavisi başlandı. Tedavinin üçüncü gününde intestinal perforasyon gelişti. Laparotomi yapıldı ve jejunal perforasyonlar saptandı. Perforasyonlar primer olarak sütüre edildi. Operasyondan sonra primer sütür yerinden anostomoz kaçağı saptandı. Hasta sepsis ilişkili kardivovasküler kollaps nedeniyle öldü.

Pam Tıp Derg 2014;7(1):67-69

Anahtar sözcükler: jejunal perforasyon, peritoneal diyaliz, peritonit.

\section{Introduction}

Peritonitis is a major complication of peritoneal dialysis (PD) therapy and is an important reason for withdrawals in PD patients. Touch contamination, catheter-related contamination, hematogenous spread and biofilm formation are the main factors for the development of PD-related peritonitis. However, peritonitis can be induced by underlying pathology of the gastrointestinal tract such as cholecystitis, and appendicitis [1]. In these conditions, peritonitis is known as secondary peritonitis. Secondary peritonitis shows significant mortality. For efficient treatment, early diagnosis and dynamic treatment are necessary.

Here in, we report the case of a patient who developed jejunal perforation due to PDreleated peritonitis which is a rare complication.

\section{Case Presantation}

A73-year-old man, maintained on continuous ambulatory peritoneal dialysis (CAPD) for 3 years, because of, presented to our hospital with complaints of abdominal pain, vomiting, fever and a cloudy dialysate fluid.

Havva Cilan

Yazışma Adresi: Mardin Devlet Hastanesi, Mardin

e-mail: havvacilan@hotmail.com 
The patient had end-stage renal disease due to hypertension. His heart rate, blood pressure, respiratory rate and axillary temperature were 100 beats/minute, 120/70mmHg, 24 breaths/ minute, and $38{ }^{\circ} \mathrm{C}$, respectively. There was a CAPD catheter in the left part of the abdomen. His exit site and tunnel were normal. On physical examination, the abdomen was distended and tender, with decreased bowel sounds. Abdominal X-Ray showed dilated loops of the small bowel with air-fluid levels and no sub diaphragmatic gas. Causes as apendicitis, cholecyticis or intraabdominal abcesswere investigated by abdominal ultrasonography and computed tomography (CT) but none were found. In the abdominal ultrasonography, a dilated small intestine with fluid accumulation in the lumen and decreased intestinal peristalsis were detected. A nasogastric tube was inserted and gastric contents were aspirated. The clinical laboratory data were: white blood cell count (WBC), $18200 / \mathrm{mm}^{3}$; WBC in the dialysate, $21900 / \mathrm{mm}^{3}$. A gram stain of the dialysate fluid was negative. He was treated empirically with intraperitoneal cefazolin ( $2 \mathrm{gr} /$ day) and amikacin (500 mg/once a week) for suspected PD-related peritonitis. The culture of peritoneal dialysis fluid was negative.

Three days after admission, severe abdominal pain with rebound tenderness and muscle defense developed. The peritoneal drainage fluid was cloudy with a yellow-green color. WBC and peritoneal fluid WBC increased to 23070 / $\mathrm{mm}^{3}$, and $23070 / \mathrm{mm}^{3}$, respectively. Abdominal X-Ray showed multiple air-fluid levels and no subdiaphragmatic free air (Figure 1). Computed tomography (CT) scan revealed minimal free air pockets in the peritoneal cavity, which could be related to the CAPD itself, diffuse thickening and edema of the small intestine (Figure 2). A laparotomy was performed because of suspected intestinal perforation, revealing two isolated perforations of the jejunum on the longitudinal axis which were $0.7 \mathrm{~cm}$ and $1.5 \mathrm{~cm}$ length, and $25 \mathrm{~cm}$ distal from ligament of Treitz. The perforations were sutured primarily, bilateral drainage catheters were placed in the abdomen, and the Tenckhoff catheter was removed. A non- tunneled catheter was placed into the right jugular vein for hemodialysis. The second culture of the dialysate fluid grew Enterobacter cloacae. Treatment was continued with intravenous piperacillin-tazobactam (2.25 gr/every $4 \mathrm{~h}$ ) and metronidazole (500 mg /every $12 \mathrm{~h}$ ). On the seventh day after the surgery, his general condition rapidly deteriorated and his blood pressure dropped to $85 / 40$ $\mathrm{mmHg}$. Bilious fluid drained from the drainage catheter. A re-laparotomy was performed. Anastomotic leakage from the primary suture region was detected and repaired. The patient was transferred to the intensive care unit. Postoperative sepsis ensued and the patient died 10 days after re-laparotomy.

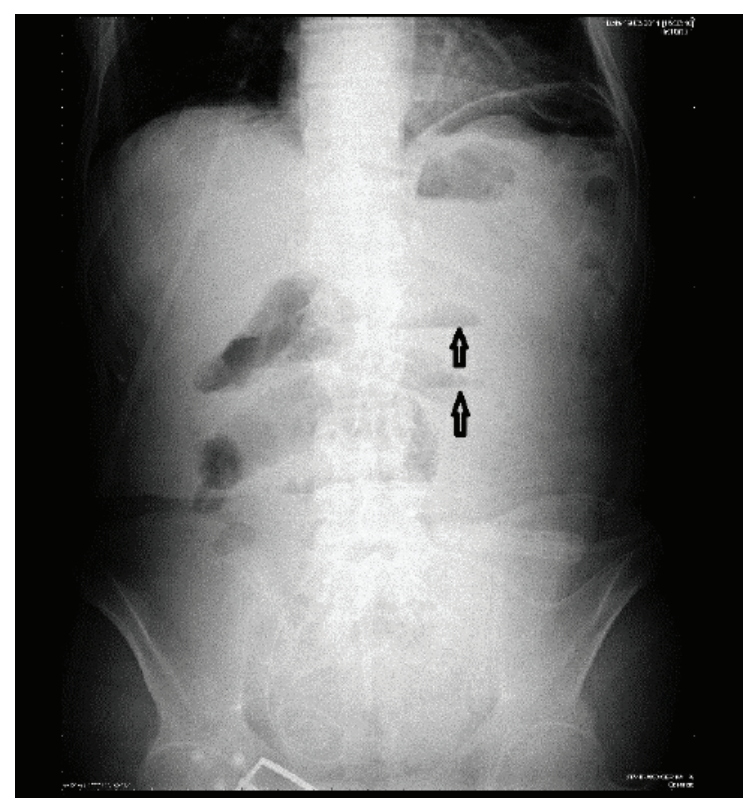

Figür 1. Abdominal X-Ray showed multiple airfluid levels

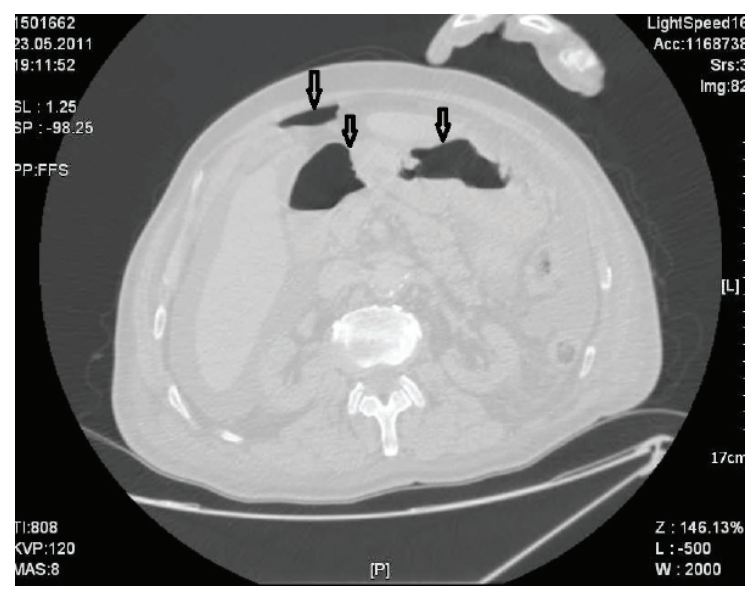

Figür 2. Computed tomography (CT) scan revealed minimal free air pockets in the peritoneal cavity, diffuse thickening and edema of the small intestine. 


\section{Discussion}

Peritonitis secondary to intra-abdominal pathology represents between $3,5 \%$ and $25 \%$ of the published series of PD-associated peritonitis; and approximately $10 \%$ of all patients treated with PD develop this complication, which carries a mortality rate of approximately $50 \%$ [2]. Intestinal perforation is a rare but very dangerous and mortal complication of PD. It is always more difficult to diagnose bowel perforation in PD patients with peritonitis and surgery is often delayed. The majority of cases have occurred upon insertion of stylet catheter for the acute dialysis [3]. The mortality rate from surgical peritonitis in PD patients was $46.3 \%$ (19/41 cases), compared to $7.5 \% \quad(12 / 161$ cases, $p<0.0001)$ for all other peritonitis cases taken as a group [2]. In one study, a laporotomy perforated appendicitis was found to be the cause of peritonitis in three patients whereas perforated diverticülitis was present in two. There was a 16,7 percent operative mortaliy rate [4]. Wellington and Rody [5] reported seven cases of polymicrobial peritonitis with an underlying colonic source identified at laparotomy in each: five had perfored diverticülitis and two had ischemic colitis. Operative mortality in their study was $50 \%$. These patients developed peritonitis secondary to intestinal perforations. We present a case of two isolated jejunal perforations due to PD-related peritonitis. In the literature, there are two cases of perforation in PD patient $[6,7]$.

The jejunal perforation is exceedingly rare in non-PD population. There are several casereports of jejunal perforation in the literature. Its causes include infections, inflammatory bowel disease, ischemia, injury from radiation therapy, blunt abdominal trauma, cancer, and swallowed foreign bodies [8,9]. Kurultak [10] et al. presented a case of intestinal perforation secondary to PD peritonitis. A laparotomy was performed and revealed adhesive ileus with cecal perforation, requiring large-bowel resection, and tube cecostomy but the patient died due to sepsis. The isolation of single or multiple enteric pathogens, particularly Escherichia coli, from the dialysate should alert the clinician to the possibility of an intraabdominal emergency [5]. To prevent high morbidity and mortality, early evaluation by a surgeon and early surgery is important. In previous studies, delay in diagnosis was reported to range from 3 to 21 days (average 10 days) [4,5]. In our case, we isolated Enterobacter cloacae on the second culture of the dialysate fluid. It was negative on the first culture of the peritoneal effluent but the cell count of dialysate effluent was reduced. The appearance of yellow-green color in the peritoneal dialysate alerted us for intestinal perforation. On the third day of the treatment, surgery was performed for bowel perforation in the early period. The second operation was performed because of surgerical complications but our patient died due to sepsis associated with cardiovasular collapse.

In conclusion, we recommend that patients should be reevaluated daily and that clinicians should check the peritoneal drainage fluid for early diagnosis of intestinal perforation daily.

Conflict of Interest: The authors report no conflict of interest.

\section{References}

1. Burkart MJ. Diagnosis of peritonitis in peritoneal dialysis. http://www.uptodate.com/contents/diagnosisof-peritonitis-in-peritoneal-dialysis? Accessed February 1, 2011.

2. Kern EO, Newman LN, Cacho CP, Schulak JA, Weiss MF. Abdominal catastrophe revisited: the risk and outcome of enteric peritoneal contamination. Perit Dial Int 2002;22:323-334.

3. Simkin EP, Wright FK. Perforating injuries of the bowel complicating peritoneal catheter insertion. Lancet 1968;1:64.

4. Carmeci C, Muldowney W, Mazbar SA, Bloom R. Emergency laparotomy in patients on continuous ambulatory peritoneal dialysis. Am Surg 2001;67:615618.

5. Wellington JL, Rody K. Acute abdominal emergencies in patients on long-term ambulatory peritoneal dialysis. Can J Surg 1993;36:522-524.

6. Korzets Z, Golan E, Ben-Dahan J, Neufeld D, Bernheim J. Decubitus small-bowel perforation in ongoing continuous ambulatory peritoneal dialysis. Nephrol Dial Transplant 1992;7:79-81.

7. Yamamoto $\mathrm{Y}$, Mure T, Sano K, Hirano H, Osawa G. Spontaneous jejunal perforation in continuous ambulatory peritoneal dialysis. Nephron 1993;64:161-162.

8. Butler JS, Collins CG, McEntee GP. Perforated jejunal diverticula: a case report. J Med Case Reports 2010;4:172.

9. Kostantinidis C, Pitsinis V, Fragulidis G. Isolated jejunal perforation following blunt abdominal trauma. Ulus Travma Acil Cerrahi Derg 2010;16:87-89.

10. Kurultak I, Altay M, Duranay M. Fatal cecal perforation complicating PD peritonitis. Perit Dial Int 2008;28:329-330. 